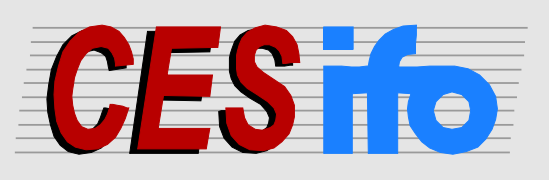

\title{
Working
}

Papers

www.cesifo.org/wp

\section{Dynamics and Time Scope of Post War Recovery Required for Compensating Civil War Economic Losses}

\author{
Chang Woon Nam \\ Jan Schumacher
}

CESIFO WORKING PAPER NO. 4361

Category 6: Fiscal Policy, Macroeconomics and Growth August 2013
An electronic version of the paper may be downloaded
- from the SSRN website: Www.SSRN.com
- from the RePEc website: Www.RePEc.org
- from the CESifo website: www.CESifo-group.org/wp

\section{CESifo}




\title{
Dynamics and Time Scope of Post War Recovery Required for Compensating Civil War Economic Losses
}

\begin{abstract}
Civil war is often caused by poverty, and further demolishes existing capital. Such a vicious circle is detrimental for economic development of countries experiencing civil war. Civil war may also contribute to creative destructions of traditional economic, social and political system, leading to a more rapid post-war growth. Until now little research exists tackling problems whether and how rapidly civil war victims recover from such negative events in the sense economic losses are reversed. Based on a present value model this study estimates dynamics and time scopes of post-war recovery required for compensating civil war GDP losses in several countries.
\end{abstract}

JEL-Code: F510, O110, O550, P520.

Keywords: civil war, GDP losses, long-term post-war recovery, developing countries, present value model.

Chang Woon Nam

Ifo Institute - Leibniz-Institute for

Economic Research

at the University of Munich

Poschingerstraße 5

Germany - 81679 Munich

nam@ifo.de
Jan Schumacher

University of Bundeswehr Munich

Werner-Heisenberg-Weg 39

85577 Neubiberg

Germany

jan.schumacher@unbw.de 


\section{Introduction}

Although the number of civil wars has gradually declined over the last twenty-five years, they still significantly threaten the development of some countries and regions, especially in Africa and Asia (World Bank, 2011). Civil war is mostly caused by poverty, ${ }^{1}$ and further destroys existing physical and human capital, while also damaging social and political institutions at the same time. Following this logic, such a vicious circle appears to be seriously detrimental for the economic development of a country experiencing a civil war. Consequently, the failure of post-war economic recovery would, in turn, increase the risk of facing the poverty-conflict trap and lead the country to slip back into civil conflict, and the cycle would start again (Collier, 1999; Collier et al., 2003). ${ }^{2}$ Moreover civil wars are assessed to be contagious, since refuge flows, diseases, lawlessness, and the illicit trades in drugs, arms and minerals generate some negative cross-border spill-over effects into the neighboring countries (Murdoch and Sandler, 2002 and 2004; Collier et al., 2003; Blattmann and Miguel, 2010; Bosker and de Ree, 2010). Such transnational spreads of negative effects tend to accelerate the economic down-turn of the entire region, which, in turn, makes a rapid postwar recovery of the initial victim also difficult due to its close economic relationship with its surroundings.

\footnotetext{
${ }^{1}$ According to World Bank (2011), a country that suffered from major violence between 1981 and 2005 has a poverty rate 21 percentage points higher than that of a country lacking such event at the same period of time.

2 “[...] conflicts often are not one-off events, but are ongoing and repeated: 90 percent of the last decade's civil wars occurred in countries that had already had a civil war in the last 30 years" (World Bank, 2011, p. 2).
} 
There have been a number of serious empirical investigations on the immediate economic loss during a civil war. Collier (1999) argues that during civil war countries appear to grow around 2.2 percentage points more slowly than during peace. Consequently after a typical civil war of seven years duration, incomes would be approximately $15 \%$ lower than if the war had not taken place. The cumulative loss of income during the war would be equal to ca. $60 \%$ of a pre-war year's GDP (see also Collier, 1999). According to Stewart et al. (2001), fourteen (among the investigated 18) countries suffered from the $3.3 \%$ reduction of the average annual per capita GNP during the conflict. In other words, the cumulative loss of income during the 7 years warfare would amount to more than $85 \%$ of a pre-war year's per capita GNP level in these 14 civil war victim countries. Furthermore, World Bank (2011) estimates the average economic cost of civil war to be more than 30 years of GDP growth for a medium-size developing country.

Apart from the destruction of production factors (such as human resources, production facilities and physical infrastructure) already mentioned above, some aditional reasons for the acceleration of economic decline caused by civil wars include in particular: (a) crowding out of government expenditures for provision of infrastructure and welfare programs through the expansion of military spending; and (b) human and capital flight - frightened people escape from their own country and protect their assets by shifting them abroad (Murdoch and Sandler, 2004). According to Knight, Loayza and Villanueva (1996) and Collier et al. (2003), the GDP share of military expenditure grows from $2.8 \%$ to $5.0 \%$ on average, while the additional increase in military spending by $2.2 \%$ of GDP, sustained over the seven years of civil war, would generally lead to a permanent loss of ca. $2 \%$ of GDP. For a typical civil-war country, as 
Collier and Sambanis (2002) suggest, the average share of private wealth held in foreign countries amounts to $9 \%$ prior to the conflict but this share rises to around $20 \%$ by the end of the civil war.

As already mentioned above, civil war tends to not only reduce the country's own growth rate but also significantly harm economic development across an entire region (Buhaug and Gleditsch, 2008). As most countries have several number of neighbors, the negative neighborhood effects of civil war has often been seen as a major multiplier of the economic cost caused by the conflict (Easterly and Levine, 1998). Apart from the collateral damage to infrastructure and capital caused by the battles fought in neighboring states, especially when battles take place close to the border, major reasons for the reduction of neighbor's growth rates encompass, for example: (i) immediate economic burden related to the refugee population; (ii) increases in arms race and military expenditures caused by the threat from the civil war country; (iii) disruption of trade and growing international transport costs, especially for landlocked countries; and (iv) bad reputation of the conflict region for (foreign) investors (Murdoch and Sandler, 2004). According to Collier et al. (2003), having a neighbor at war reduces the annual growth rate by around 0.5 percentage points. In addition "a country making development advances, such as Tanzania, loses an estimated 0.7 percent of GDP every year for each neighbor in conflict" (World Bank, 2011, p. 5). Therefore, policies to bring peace to civil-war-torn countries have a positive return not only for the conflictridden country, but also for its neighbors.

The rebound in post-war GDP growth appears to be less surprising. "War disrupts economic activity, contracting income. Thus, the mere resumption of pre-war economic activity would result in a relatively high post-war economic growth rate, 
given the fact of computing the growth rate over a low base" (Davies, 2008, p. 4). To the extent that civil war impacts are limited to the destruction of capital, Bellows and Miguel (2006) suggest that the neoclassical model predicts the rapid post-war growth in the short-to-medium term (because the marginal productivity of capital would be high due to a reduced capital stock), converging back to steady-state growth. Peace after the civil war may also provide an additional dividend, since it tends to reverse the flight of capital and labor which would, in turn, accelerate economic growth (Collier, 1999).

On the other hand, Collier (1999) argues that "the restoration of peace [after civil war] does not necessarily produce a dividend. Peace does not recreate either the fiscal or the risk characteristics of the pre-war economy, [since] there is a higher burden of military expenditure and a greater risk of renewed war. The desired capital stock is consequently lower than had there been no war, although being higher than that desired during the war. [In addition] if a civil war lasts only a year, it was [empirically] found to cause a loss of growth during the first five years of peace of $2.1 \%$ per annum, a loss not significantly different from that had the war continued. However, if the war has been sufficiently long the capital stock will have adjusted to a level below that desired in post-war conditions. In this case capital repatriation enables the economy to grow more rapidly than during the pre-war period" (Collier, 1999, p. 181).

There are also some alternative views that civil wars may lead to a 'creative destruction' of the traditional economic, social and political system which would eventually lead to a higher rapid growth in the long run. Post-civil war developments are often characterized by multiple transition processes - the transition from war to peace generally accompanied by democratization, decentralization and market liberalization (Reychler and Langer, 2006). Therefore a success in timely transformation 
of war-torn societies into peaceful and stable ones would well provide a foundation for the rapid long-term economic growth. ${ }^{3}$ According to Bellows and Miguel (2006), civil war has had a positive long-term impact on institutions in some parts of Sierra Leone. If this were true for the country as a whole, it could imply a higher long-term growth than would have occurred in the absence of war (see also Davies, 2008). Moreover, according to the popular endogenous growth theory a country of which capital stock is destroyed by a civil war tends to compensate its loss with new capital that embodies more modern technology, which would, in turn, trigger the long-term growth rates of total factor productivity and GDP per capita (Aghion and Howitt, 1998). In this context Kang and Meernik (2005) see a rapid economic recovery in the immediate post-civil war period absolutely necessary in order to realize stable long-term economic growth, while international aid speeds time to the short-term recovery (Flores and Nooruddin, 2009). If the creative destruction occurs, one can also eventually expect positive longterm external effects of warfare for the neighboring countries as well.

Are civil wars associated with long-term growth optimism? Very little research has been carried out until now aimed at identifying whether and how rapidly victims of civil war recover from such serious negative events in the sense output losses are reversed (see also Cerra and Saxena, 2008). The major purpose of our article is to deliver some answers to these crucial questions. More precisely, this study estimates, based on a simple present value model, the time scope and the dynamics of post-war recovery required for compensating the civil-war GDP losses in several selected countries like Algeria, Angola, Lebanon, Mozambique, Sierra Leone and Uganda. All of

\footnotetext{
${ }^{3}$ Tilly (1975) shows how war promoted state formation and nation building in Europe historically, ultimately strengthening institutions.
} 
them experienced the rebound of GDP growth after the years of continuous economic decline caused by the civil war but the dynamics of recovery differs from one country to another. Instead of highlighting generalized empirical facts identified based on a large number of country samples, we primarily emphasize in the analysis the country-specific development trends and characteristics in these survey nations.

This study is structured as follows. Following this introduction, section 2 describes the present value model adopted to compare the potential GDP loss caused by a civil war and the potential gain led by the strong post-war economic recovery. The third section delivers some empirical findings explaining different recovery patterns in the investigated victim countries and examines the dynamics and time scopes of postwar development needed for compensating the civil war losses. The final section summarizes the major findings and concludes.

\section{Model}

Assume that a country experiences a civil war only once and has a rebound in economic growth caused by this event at year $R$, whereas the potential post-war economic recovery thereafter is much stronger than the potential growth trend expected in the absence of civil war. Under the additional assumption that the economy starts to decline simultaneously as the civil war begins, the polynomial function (B) in Figure 1 shows the potential GDP growth trend after the civil war beginning at year $E{ }^{4}$ while the polynomial function $(A)$ demonstrates the anticipated potential GDP growth trend in the absence of civil war, which is delivered under the consideration of the GDP changes in

\footnotetext{
${ }^{4}$ Here we assume that the economic downturn starts as the civil war begins.
} 
the pre-war years. Moreover, Figure 1 illustrates the case that economic decline continues until $R$, although the civil war ends earlier. Consequently the economic rebound emerges immediately after $R$. Since the function $(B)$ is expected to run more rapidly than (A) after $R$, a break-even point between the two GDP growth functions can be expected at the year $M$. In this case one can calculate the economic loss caused by civil war, which is denoted by the area $L$ between the years $E$ and $M$, and compare it with the economic gain resulted from the difference between the functions $(B)$ and $(A)$ as shown by the area $P$ between $M$ and a given year $G$ in Figure 1 .

\section{Figure 1 Economic Recovery from Civil War: A General Approach}

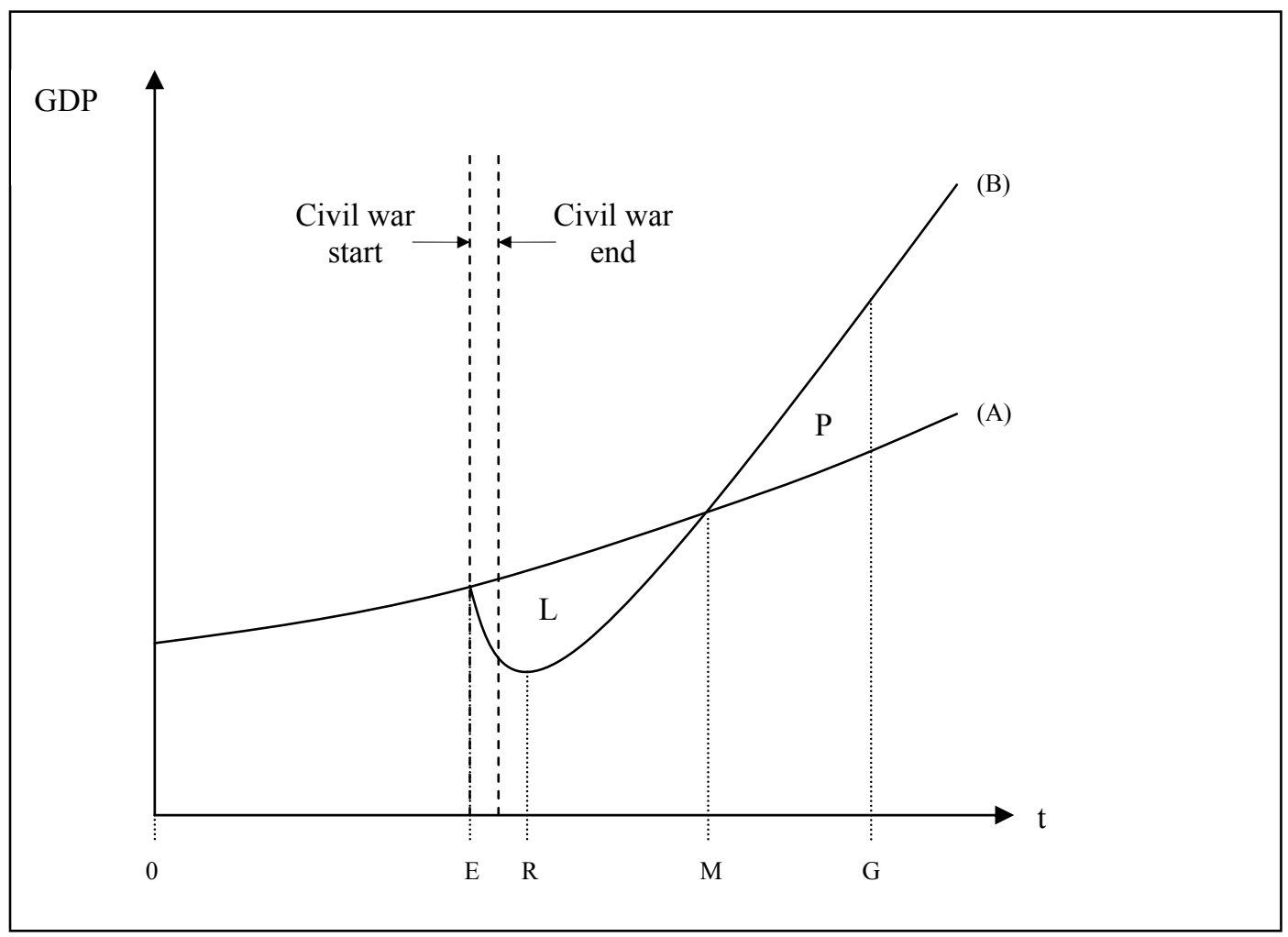

Source: Authors' conception. 
For the measurement of the economic loss as well as the economic gain mentioned above, we adopt the simple present value model. The present value of a country's GDP loss caused by the civil war at the year of civil war begin $(t=E)$ can be then expressed as

(1) $P V_{L, t=E}=\int_{E}^{M}(A) e^{-r(t-E)} d t-\int_{E}^{M}(B) e^{-r(t-E)} d t$

where $A=$ potential GDP growth trend in the absence of civil war in the course of time $t ; B=$ potential GDP growth trend after the civil war begin - also as a function of $t ; r=$ discount rate; and $t=$ year.

On the other hand, equation (2) shows the present value of economic gain at $t=$ $M$ which results from the difference between the anticipated GDP growth functions $(B)$ and $(A)$ within the time interval from $M$ to $G$

(2) $\quad P V_{P, t=M}=\int_{M}^{G}(B) e^{-r(t-M)} d t-\int_{M}^{G}(A) e^{-r(t-M)} d t$

Hence, measured in terms of the present value at $t=E$, a complete compensation of the economic loss caused by the civil war takes place by the rapid economic recovery within a given period of time from $M$ to $G^{*}$, when

$$
P V_{L, t=E}-\frac{1}{(1+r)^{M-E}} P V_{P^{*}, t=M}
$$




$$
=\int_{E}^{M}(A) e^{-r(t-E)} d t-\int_{E}^{M}(B) e^{-r(t-E)} d t-\frac{1}{(1+r)^{M-E}}\left\{\int_{M}^{G^{*}}(B) e^{-r(t-M)} d t-\int_{M}^{G^{*}}(A) e^{-r(t-M)} d t\right\}=0
$$

where $G^{*}-M$ denotes the time period required for the full compensation of the GDP losses.

\section{Empirical Findings}

For the empirical analysis GDP data expressed in terms of the '1990 international dollars' from 1950 to 2008 are used. Such internationally comparable GDP data have been collected, estimated and systematically compiled by A. Maddison - see http://www.ggdc.net/maddison/. This database enables to identify those Asian and African countries which had a civil war in the observed time period, of which negative impacts on GDP development are particularly serious. As already mentioned above, civil wars not only destroy physical capital but also tend to reduce the size of population significantly since such wars kill people and, at the same time, cause massive crossborder human flights. Due to this reason it appears to be more sensible to consider the total GDP change than that of the GDP per capita, when examining the negative economic effects of such wars.

As was the case in Figure 1 the two vertical lines in Figure 2 indicate the start and the end of the civil war (see different civil war durations in the investigated countries in Table 1), while the gray line illustrates the changes of actual GDP values between 1950 and 2008. In the following country figures the year 1950 is set as the year 0 , and in the selection of survey countries it was borne in mind that the pre-war GDP 
trend function (A) and the GDP trend function (B) since around the outbreak of the civil war were estimated based on sufficient observations. A decline in GDP started one-year prior to the beginning of the war in most investigated African countries (Algeria, Angola, Mozambique and Uganda), because there has already been considerable unrest in the country which significantly impedes economic development (Table 1). Therefore, when identifying the GDP trend function (B) and calculating the civil-war economic loss, the GDP reductions occurring in the year before the warfare began should also be adequately considered. Yet Lebanon appears to be an exception: in this country the economic downturn emerged firstly five years after the civil war started in 1974. 
Table 1 Civil War Duration and Some Immediate Economic Consequences

\begin{tabular}{|c|c|c|c|c|c|c|c|c|}
\hline & \multirow{2}{*}{$\begin{array}{l}\text { Civil war } \\
\text { duration }\end{array}$} & \multicolumn{2}{|c|}{$\begin{array}{l}\text { Start of economic down-turn } \\
\text { caused by civil war }\end{array}$} & \multicolumn{2}{|c|}{$\begin{array}{l}\text { Actual economic trough } \\
\text { led by civil war }\end{array}$} & \multirow{2}{*}{$\begin{array}{c}\text { Actual GDP } \\
\text { in } 2008 \\
\text { (Billion 1990 } \\
\text { intern. dollars) }\end{array}$} & \multicolumn{2}{|c|}{ Estimated break-even point } \\
\hline & & $\begin{array}{l}\text { Starting } \\
\text { year } \\
(E)\end{array}$ & $\begin{array}{c}\text { Actual GDP at } E \\
\text { (Billion } 1990 \\
\text { intern. dollars) }\end{array}$ & $\begin{array}{l}\text { Trough } \\
\text { year } \\
(R)\end{array}$ & $\begin{array}{c}\text { Actual GDP at } R \\
\text { (Billion } 1990 \\
\text { intern. dollars) }\end{array}$ & & $\begin{array}{l}\text { Year } \\
(M)\end{array}$ & $\begin{array}{l}\text { Number of years } \\
\text { taking between civil } \\
\text { war end and } M\end{array}$ \\
\hline Algeria & $1991-2002$ & 1990 & 73.9 & 1994 & 71.9 & 118.9 & 2022 & 19 \\
\hline Angola & $1975-2002$ & 1974 & 10.2 & 1993 & 5.2 & 21.1 & 2059 & 57 \\
\hline Lebanon & $1975-1990$ & 1979 & 8.9 & 1988 & 6.1 & 17.7 & 2071 & 81 \\
\hline Mozambique & 1977-1992 & 1976 & 13.6 & 1985 & 12.0 & 46.0 & 2034 & 42 \\
\hline Sierra Leone & 1991-2002 & 1991 & 4.3 & 1999 & 1.9 & 4.3 & 2010 & 8 \\
\hline Uganda & 1979-1986 & 1978 & 8.3 & 1980 & 7.1 & 31.6 & 1997 & 11 \\
\hline
\end{tabular}

Source: World Bank (2011); Collier et al. (2003); historical statistics compiled by A. Maddison (http://www.ggdc.net/maddison/); authors' own calculation. 
Unlike the conventional wisdom forecasting that the emergence of economic upturn can be expected firstly in the post-war years, Table 1 and Figure 2 clearly suggest that in all the investigated countries, except Lebanon, such GDP rebounds have taken place within the civil war period (i.e. while the conflict is still in process). For example, in Algeria the country experienced a civil war between 1991 and 2002 - the GDP started to decline in 1990 and reached the trough point $R$ (with the GDP level of 71.9 billion 1990 international dollars) in 1994. In other words, GDP has gradually grown since 1995 in this country (see Table 1). This interesting finding indicates among others that, as the civil war starts to lose intensity and slowly head to a ceasefire, the extent to which the production factors get additionally damaged in a year tends to gradually decrease, and that the adjustment and the responsiveness of economic activities to the emergence of political thaw and/or the signs of possible peace appear to be extremely speedy within the civil war periods.

For the purpose of comparing the time scope and the dynamics of post-war recovery required for compensating the civil-war GDP losses in selected six countries, the identification of the break-even-year $M$ appears to be the first task, where the anticipated two GDP growth trend functions $(A)$ and $(B)$ intersect each other. Regardless of the investigated countries, a uniform interest rate of $5 \%$ is adopted as the discount rate for the purpose of computing the present value of GDP losses and gains at the initial year of the economic downturn. Repeatedly, apart from the speed and scope of economic decline led by the civil war, the variation of growth dynamics of the trend functions $(A)$ and $(B)$, in particular after the rebound, determines such break-even-years in the individual countries. 


\section{Figure 2 Economic Recovery from Civil War: Country Cases}
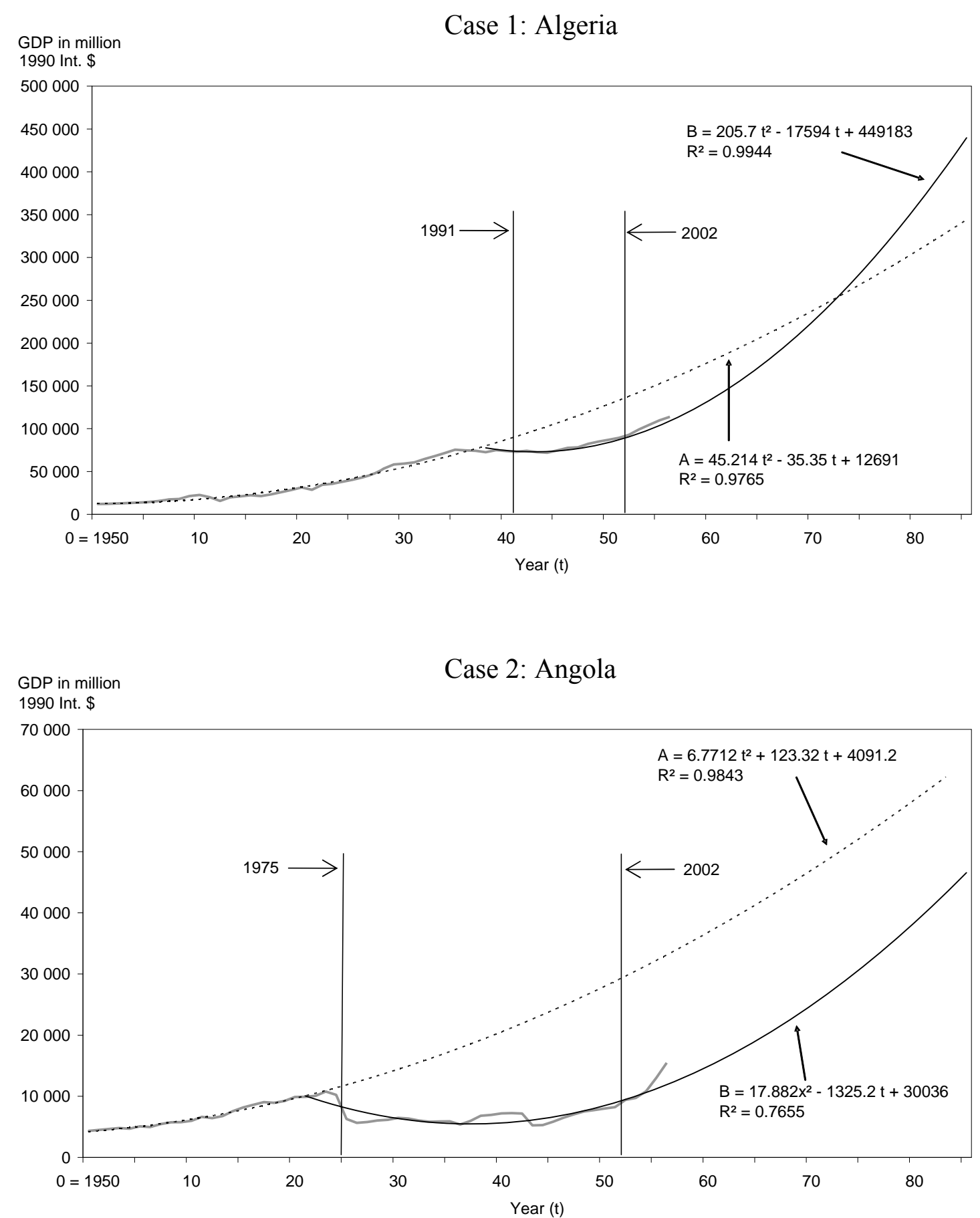
Figure 2 (continued)
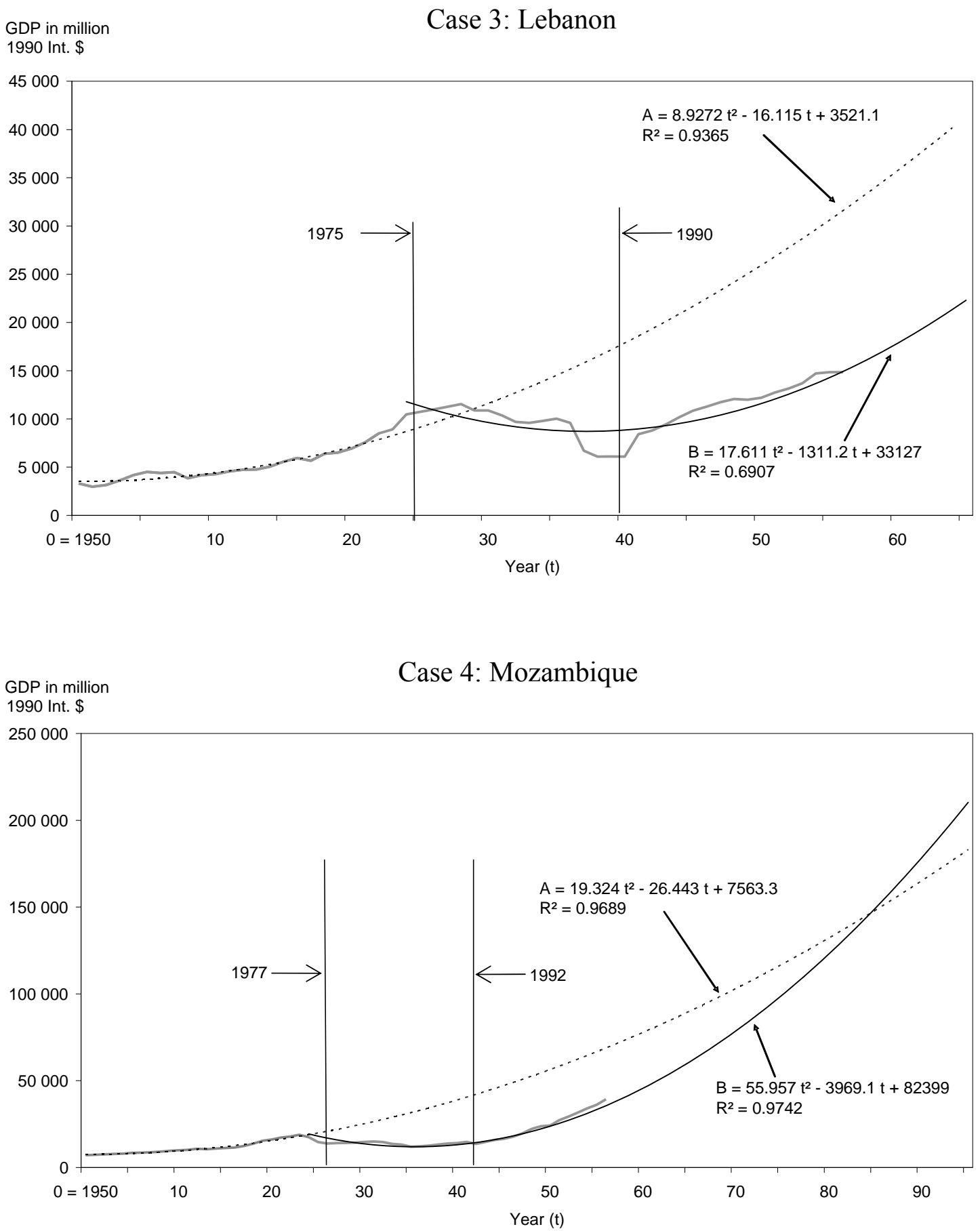
Figure 2 (continued)
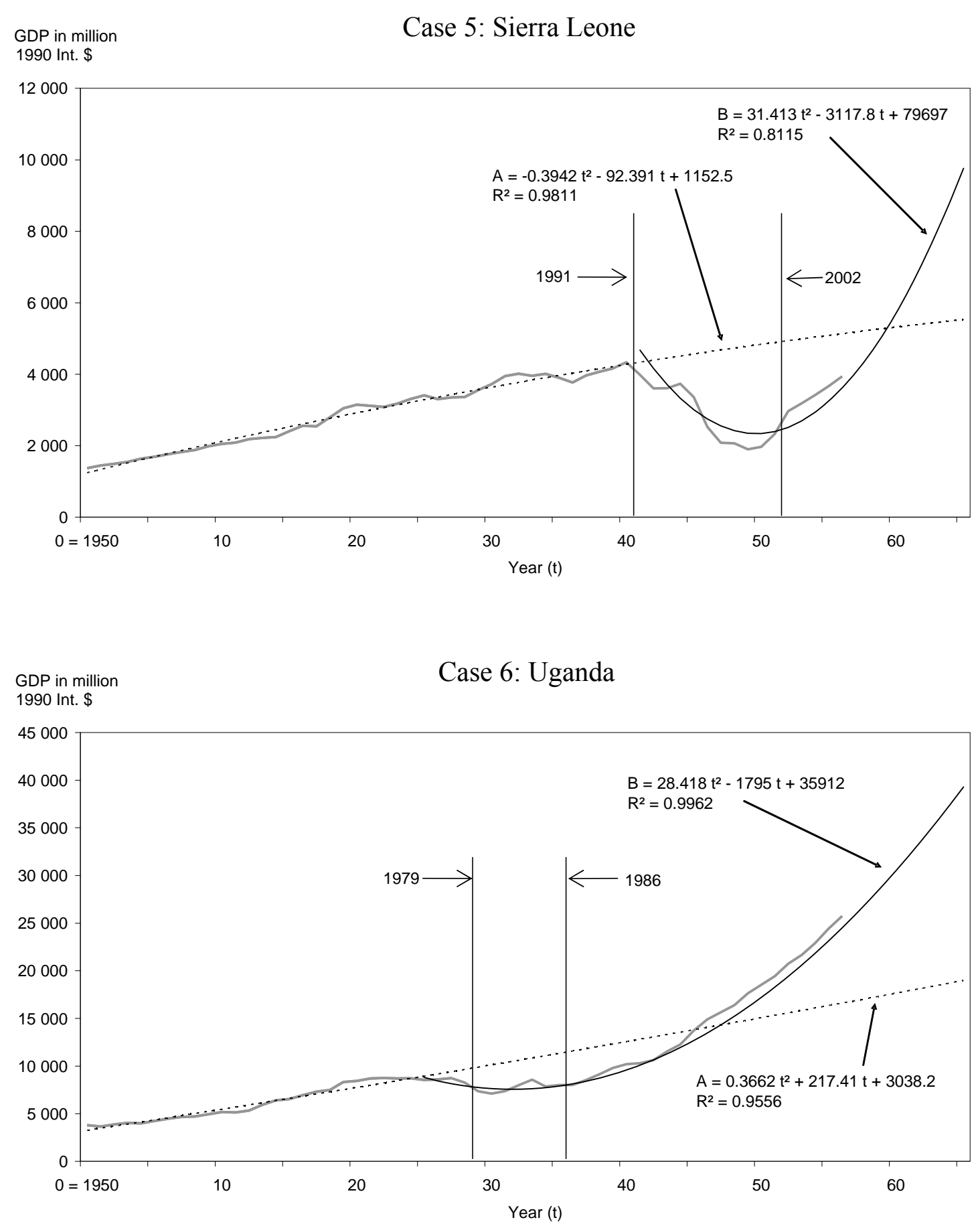

Note: Two vertical lines indicate the start and the end of the civil war. The gray line shows the actual GDP values between 1950 and 2008.

Source: Table 2; historical statistics compiled by A. Maddison (http://www.ggdc.net/maddison/); authors' own calculation. 
First of all, in countries like Angola, Mozambique and Lebanon the actual (i.e. observed until 2008) and also anticipated GDP development thereafter - expressed in terms of the function $(B)$ - appears to be less sufficient to catch up the pre-war growth trend $(A)$ in the foreseeable future: the intersecting between the two trend functions is anticipated to occur in Mozambique firstly in 2034, in Angola in 2059, and in Lebanon in 2071. In other words, such a break-even point will prevail 81 years after the end of civil war in Lebanon, while the comparable time-scope will amount to 57 years in Angola and 42 years in Mozambique (see Table 1). After all these individual years the aforementioned countries can start to slowly compensate their economic losses. With the adopted interest rate of 5\% for discounting future GDP level, the present value of entire GDP loss at the starting year of economic downturn caused by the warfare is estimated to reach approximately $150.7,220.8$ and 346.2 billion 1990 international dollars in Lebanon, Angola and Mozambique, respectively (see Table 2). The huge size of GDP loss in these countries can be well highlighted, if one compares such a loss in a country with the annual GDP level of the same country at the starting year of economic downturn. For example, Lebanon's GDP amounted to 8.9 billion 1990 international dollars in 1979, compared to Angola's 10.2 and Mozambique's 14.6 billion 1990 international dollars in 1974 and 1975, respectively (see Table 1). Namely, at the starting year of economic downturn caused by the civil war the share of actual annual GDP measured in terms of the calculated present value of total GDP loss ranges solely from $4 \%$ to $6 \%$ in these countries. From these less favorable empirical facts one can easily expect the fatal consequences of large scale GDP losses caused by the civil war in these countries: the compensation of civil war economic loss is hardly possible in the foreseeable future (see Table 2). 
Table 2 Size of Civil War Loss Calculated Based on Two Potential GDP Growth Trends

\begin{tabular}{|c|c|c|c|}
\hline & Algeria & Angola & Lebanon \\
\hline $\begin{array}{l}\text { Potential GDP growth trend in the } \\
\text { absence of civil war }(A)\end{array}$ & $\begin{array}{c}A=45.214 t^{2}-35.35 t+12691 \\
R^{2}=0.9765 \\
\frac{d A}{d t}=90.428 t-35.35\end{array}$ & $\begin{array}{c}A=6.7712 t^{2}+123.32 t+4091.2 \\
R^{2}=0.9843 \\
\frac{d A}{d t}=13.5424 t+123.32\end{array}$ & $\begin{array}{c}A=8.9272 t^{2}-16.115 t+3521.1 \\
R^{2}=0.9365 \\
\frac{d A}{d t}=17.8544 t-16.115\end{array}$ \\
\hline $\begin{array}{l}\text { Potential GDP growth trend after the } \\
\text { civil war begin }(B)\end{array}$ & $\begin{array}{c}B=205.7 t^{2}-17595 t+449183 \\
R^{2}=0.9944 \\
\frac{d B}{d t}=411.4 t-17595\end{array}$ & $\begin{array}{c}B=17.882 t^{2}-1325.2 t+30036 \\
\quad R^{2}=0.7655 \\
\frac{d B}{d t}=35.764 t-1325.2\end{array}$ & $\begin{array}{c}B=17.611 t^{2}-1311.2 t+33127 \\
\quad R^{2}=0.6907 \\
\frac{d B}{d t}=35.222 t-1311.2\end{array}$ \\
\hline $\begin{array}{l}\text { Estimated present value of civil war } \\
\text { loss }(L) \text { in billion } 1990 \text { International } \$\end{array}$ & 455.0 & 220.8 & 150.7 \\
\hline Break-even-year $(M)$ & 2022 & 2059 & 2071 \\
\hline $\begin{array}{l}\text { Number of years after } M \text { required to } \\
\text { compensate the civil war loss }\end{array}$ & 42 & $\infty$ & $\infty$ \\
\hline
\end{tabular}


Table 2 (continued)

\begin{tabular}{|c|c|c|c|}
\hline & Mozambique & Sierra Leone & Uganda \\
\hline $\begin{array}{l}\text { Potential GDP growth trend in the } \\
\text { absence of civil war }(A)\end{array}$ & $\begin{array}{c}A=19.324 t^{2}-26.443 t+7563.3 \\
R^{2}=0.9689 \\
\frac{d A}{d t}=28.648 t-26.443\end{array}$ & $\begin{array}{c}A=-0.3942 t^{2}-92.391 t+1152.5 \\
R^{2}=0.9811 \\
\frac{d A}{d t}=-0.7884 t-92.391\end{array}$ & $\begin{array}{c}A=0.3662 t^{2}+217.41 t+3038.2 \\
R^{2}=0.9556 \\
\frac{d A}{d t}=0.7324 t+217.41\end{array}$ \\
\hline $\begin{array}{l}\text { Potential GDP growth trend after the } \\
\text { civil war begin }(B)\end{array}$ & $\begin{array}{c}B=55.957 t^{2}-3969.1 t+82399 \\
R^{2}=0.9742 \\
\frac{d B}{d t}=111.914 t-3969.1\end{array}$ & $\begin{array}{c}B=31.413 t^{2}-3117.8 t+79697 \\
R^{2}=0.8115 \\
\frac{d B}{d t}=62.826 t-3117.8\end{array}$ & $\begin{array}{c}B=28.418 t^{2}-1795 t+35912 \\
R^{2}=0.9962 \\
\frac{d B}{d t}=56.836 t-1795\end{array}$ \\
\hline $\begin{array}{l}\text { Estimated present value of civil war } \\
\text { loss }(L) \text { in billion } 1990 \text { International } \$\end{array}$ & 346.2 & 17.6 & 27.8 \\
\hline Break-even-year $(M)$ & 2034 & 2010 & 1997 \\
\hline $\begin{array}{l}\text { Number of years after } M \text { required to } \\
\text { compensate the civil war loss }\end{array}$ & $\infty$ & 13 & 18 \\
\hline
\end{tabular}

Source: Authors' own calculation. 
On the other hand, countries like Algeria, Sierra Leone, and Uganda have experienced a significantly stronger GDP growth of function $(B)$ after the rebound, compared to that demonstrated by the trend function $(A)$ in the absence of the civil war. As a consequence, a shorter time scope is required to reach the break-even-year $M$, which prevails in Uganda in 1997 and in Sierra Leone in 2010, while such intersection is likely to take place in Algeria in 2022. In other words, such a break-even point will be given 19 years after the end of civil war in Algeria, while the comparable time-scope is anticipated to reach 8 years in Sierra Leone and 11 years in Uganda (see also Table 1). In addition the present value of total GDP loss at the starting year of economic downturn appears to be rather low, amounting to approximately 17.6 and 27.8 billion 1990 international dollars in Sierra Leone and Uganda, respectively. Algeria is an exception due in part to its relatively large economic power: the country's present value of total GDP loss caused by the civil war reaches around 455.0 billion 1990 international dollars. The share of the annual GDP level - e.g. Sierra Leone: 4.3 billion 1990 international dollars (in 1990); Uganda: 8.3 billion 1990 international dollars (in 1978); and Algeria: 73.9 billion 1990 international dollars (in 1990) - expressed in terms of the present value of total GDP loss at the corresponding starting year of economic downturn amounts to approximately $25 \%$ and $30 \%$ in Sierra Leone and Uganda, respectively, while the same share reaches around 16\% in Algeria.

All these conditions appear to make the compensation of the GDP loss rather 'manageable' in these countries within a foreseeable period of time after the break-even year mentioned above. A full-scale compensation of GDP loss is expected to take place in Algeria in 2064 (i.e. 62 years after the end of civil war in 2002), Sierra Leone in 2022 (i.e. 20 years after the end of civil war in 2002), and Uganda in 2014 (i.e. 28 years after 
the end of civil war in 1986). Nevertheless, compared to the civil war durations of 7 to 11 years in these countries (i.e. from 1979 to 1986 in Uganda; and from 1991 to 2002 in Algeria and Sierra Leone), those computed 'much-longer' time periods which are required to compensate the GDP losses indicate again the fact that an economic recovery from such wars is an expensive and painful process and a serious challenge for the victims.

\section{Conclusion}

Based on a simple present value model and under the consideration of the nationspecific pre and post-war development trends in the selected countries (Algeria, Angola, Lebanon, Mozambique, Sierra Leone and Uganda), this study delivers some novel empirical findings related to the time scope and the dynamics of post-war recovery required for compensating the civil-war GDP losses. At first glance, all these victims have achieved a more favorable post-war GDP growth compared to their pre-war economic development but this is not the end of story.

First of all, unlike the wide-spread conventional idea that economic upturn would be firstly expected in the years after the end of warfare, this study clearly demonstrates the possibility of emerging a GDP rebound in many countries within the civil war period. Apart from the fact that, as the civil war starts to lose intensity and head to a ceasefire, the extent to which the production factors get additionally damaged in a year tends to decrease, this finding also suggests the speedy adjustment and responsiveness of economic activities to the emergence of political thaw and/or the signs of possible peace within the civil war periods. 
In this study the size of GDP loss caused by civil war is measured on the basis of differences between the (estimated) potential GDP growth trend since 1950 under the assumption of lacking civil war and the (estimated) potential GDP growth trend after the beginning of civil war, while the GDP decline usually started one-year prior to the war start in survey countries. More precisely, apart from the conflict duration, and the speed and scope of immediate economic decline caused by the civil war, the variation of GDP growth dynamics of both trends mentioned above (i.e. also the post-war recovery trend after the rebound) as well as the expected intersect year of these two growth functions (break-even-year) determine the economic loss in the individual victim countries. In addition to a discount rate of 5\%, GDP data expressed in terms of 1990 international dollars from 1950 to 2008 are used for the calculation of present value of civil war loss at the starting year of economic downturn which is then compared to that of economic gain triggered by the more rapid post-war recovery in the same year.

According to the computation, the intersection between the two GDP growth functions will occur 81 years after the end of civil war in Lebanon, while the comparable time scope amounts to 57 years in Angola and 42 year in Mozambique. The present value of GDP loss reaches ca. 150.7, 220.8 and 346.2 billion 1990 international dollars in Lebanon, Angola and Mozambique, respectively: such computed civil war losses are 16.9, 21.6 and 25.5 times higher than the annual GDP level of the year of economic decline in the countries in the same order. In these countries such extremely huge civil war economic losses can hardly be compensated by the post-war recovery in the foreseeable future.

In comparison Algeria, Sierra Leone, and Uganda have experienced a stronger GDP growth after the rebound. Consequently the break-even between the two potential 
growth trend functions will take place 19 years after the civil war end in Algeria, while the comparable time-scope will reach 8 years in Sierra Leone and 11 years in Uganda. The computed present value of total GDP loss at the starting year of economic decline is also lower, amounting to ca. 17.6 and 27.8 billion 1990 international dollars in Sierra Leone and Uganda, respectively, compared to 455.0 billion 1990 international dollars in Algeria. Such civil war economic losses are 3.3, 4.1 and 6.2 times higher than the annual GDP level of the year of economic decline in Uganda, Sierra Leone and Algeria, respectively. All these pre-conditions appear to make the compensation of the GDP loss achievable within a foreseeable period of time: such an event is likely to occur in Algeria in 2064 (62 years after the civil war end in 2002), Sierra Leone in 2022 (20 years after the civil war end in 2002), and Uganda in 2014 (28 years after the civil war in 1986). Yet, compared to the civil war durations of 7 to 11 years in these countries, those longer time scopes required for the compensation demonstrate again that a successful post-war economic recovery is not only a painful but also an extremely challenging process for the victim countries.

\section{References}

Aghion, P. and P. Howitt (1998), Endogenous Growth Theory, Cambridge, MA: MIT Press.

Bellows, J. and E. Miguel (2006), War and Institutions: New Evidence from Sierra Leone, American Economic Review 96, 394-399.

Blattman, C. and E. Miguel (2009), Civil War, Journal of Economic Literature 48, 357. 
Bosker, M. and J. de Ree (2010), Ethnicity and the Spread of Civil War, CEPR Discussion Paper 8055.

Buhaug, H. and K. S. Gleditsch (2008), Contagion or Confusion? Why Conflicts Cluster in Space, International Studies Quarterly 52, 215-233.

Cerra, V. and S. C. Saxena (2008), Growth Dynamics: The Myth of Economic Recovery, American Economic Review 98, 439-457.

Collier, P. (1999), On the Economic Consequences of Civil War, Oxford Economic Papers 51, 168-183.

Collier, P. and N. Sambanis (2002), Understanding Civil War: A New Agenda, Journal of Conflict Resolution 46, 3-12.

Collier, P., V. L. Elliott, H. Hegre, A. Hoeffler, M. Reynal-Querol and N. Sambanis (2003), Breaking the Conflict Trap - Civil War and Development Policy, A World Bank Policy Research Report, Washington DC and Oxford: World Bank and Oxford University Press.

Davies, V. A. B. (2008), The Macroeconomics of Post-Conflict Economic Recovery, Background Study No. 4 for the United Nations Development Program (UNDP, 2009), Post-Conflict Economic Recovery: Enabling Local Ingenuity, http://www.undp.org/cpr/content/economic_recovery/Background_4.pdf.

Easterly, W. and R. Levine (1998), Troubles with the Neighbours: Africa's Problem, Africa's Opportunity, Journal of African Economies 7, 120-142.

Flores, T. E. and I. Nooruddin (2009), Democracy under the Gun: Understanding Postconflict Economic Recovery, Journal of Conflict Resolution 53, 3-29.

Kang, S. and J. Meernik (2005), Civil War Destruction and the Prospects for Economic Growth, Journal of Politics 67, 88-102 
Knight, M., N. Loayza and D. Villanueva (1996), The Peace Dividend: Military Spending Cuts and Economic Growth, IMF Staff Papers 43, 1-37.

Murdoch, J. and T. Sandler (2002), Economic Growth, Civil Wars, and Spatial Spillovers, Journal of Conflict Resolution 46, 91-110.

Murdoch, J. and T. Sandler (2004), Civil Wars and Economic Growth: Spatial Dispersion, American Journal of Political Science 48, 138-151.

Reychler, L. and A. Langer (2006), Researching Peace Building Architecture, KUL. Cahiers Internationale Betrekkingen en Vredesonderzoek 75, Leuven: Centrum voor Vredesonderzoek en Strategische Studies.

Stewart, F., C. Huang and M. Wang (2001), Internal Wars in Developing Countries: An Empirical Overview of Economic and Social Consequences, in: Stewart, F. and V. Fitzgerald (eds.), War and Underdevelopment, vol. 1, Oxford: Oxford University Press, 67-103.

Tilly, C. H. (1975), The Formation of National States in Western Europe, Princeton: Princeton University Press.

World Bank (2011), World Development Report 2011 - Conflict, Security, and Development, Washington DC. 